\title{
The occurrence and function of $a$-type cytochromes in the aerobic respiratory chain of Comamonas percolans NCTC 1937 grown under $\mathbf{O}_{2}$-sufficient and $\mathbf{O}_{2}$-limited conditions
}

\author{
Huw D. Williams, ${ }^{*} \dagger$ Hwee B. Tan and Robert K. Poole \\ Microbial Physiology Research Group, Biosphere Sciences Division, King's College London, Campden Hill Road, \\ London W8 7 AH, UK
}

(Received 13 September 1989; revised 7 March 1990; accepted 28 March 1990)

\begin{abstract}
Intact cells of Comamonas percolans (NCTC 1937) after growth under $\mathbf{O}_{2}$-limited conditions in batch culture exhibit, in addition to $b$ - and $c$-type cytochromes, an unusual pigment absorbing variably at 588 to $594 \mathrm{~nm}$ in reduced minus oxidized difference spectra at room temperature. $\mathrm{CO}$ difference spectra suggest ligand binding by this pigment and also reveal a prominent $448 \mathrm{~nm}$ absorption minimum and CO-binding $b$ - and/or $c$-type cytochromes. Although the 588 to $594 \mathrm{~nm}$-absorbing component is reminiscent of 'cytochrome $a_{1}$ ', claimed to be a terminal oxidase in some bacteria, $\mathrm{O}_{2}$-limited cells of $C$. percolans contain no detectable haem $\mathrm{A}$. In contrast, cells grown under $\mathrm{O}_{2}$-sufficient conditions exhibit a membrane-bound cytochrome $a a_{3}$ and contain haem $\mathrm{A}$. Lowtemperature photodissociation studies of $\mathrm{O}_{2}$-sufficient cells show cytochrome $a a_{3}$ to be functional in $\mathrm{CO}$ and $\mathrm{O}_{2}$ binding and suggest that $a a_{3}$ is the terminal oxidase of a cytochrome $b$ - and $c$-containing aerobic respiratory chain. Analogous studies of $\mathrm{O}_{2}$-limited cells reveal a component absorbing, in its unliganded state, at $\mathbf{4 4 8} \mathbf{n m}$. Exposure of such CO-liganded cells to white actinic light is followed by oxidation of $b$ - and/or $c$-type cytochromes and, although the functional oxidase has not been identified, we conclude that $C$. percolans does not utilize a cytochrome oxidase of the $a_{1}$ type.
\end{abstract}

\section{Introduction}

Cytochromes of the $a$-type, i.e. haemoproteins with haem $\mathrm{A}$ as the prosthetic group, are important constituents of bacterial and eukaryotic respiratory chains. The best-studied example is cytochrome $a a_{3}$ or cytochrome $c$ oxidase (EC 1.9.3.1), which is the terminal oxidase of the mitochondrial electron transport chain (see Wikström et al., 1981, for a review). Certain bacteria also possess $a a_{3}$-type cytochromes which are similar to the mitochondrial enzyme in the complement of redox centres ( 1 haem $a: 1$ haem $a_{3}: 2$ or $3 \mathrm{Cu}$ ) and in their spectral characteristics, but which are much simpler in subunit composition, having only two or three constituent polypeptides (for reviews, see Ludwig, 1987; Poole, 1983, 1988).

The early studies of Keilin \& Warburg (for a review, see Keilin, 1966) suggested the presence in certain bacteria of an apparently related oxidase but with an $\alpha$ -

† Present address: Department of Biology, Imperial College of Science, Technology and Medicine, Prince Consort Road, London SW7 2BB, UK. maximum sufficiently removed (to shorter wavelengths) from the corresponding band of mitochondrial and Bacillus subtilis cytochromes $a a_{3}$ to warrant a distinguishing subscript. This 'cytochrome $a_{1}$ ' was confirmed as a competent oxidase in an Acetobacter strain by Castor \& Chance (1955, 1959). However, recent studies on haemoproteins resembling 'cytochrome $a_{1}$ ' in various bacteria have highlighted the functional diversity of these pigments and cast doubt on the assumption that haemoproteins with an $\alpha$-maximum at 585 to $596 \mathrm{~nm}$ (in reduced minus oxidized difference spectra) should be called 'cytochrome $a_{1}$ '. Poole et al. (1985) proposed a classification of $a_{1}$-like haemoproteins and suggested that true cytochromes $a_{1}$ should be shown to contain haem A. Few $a_{1}$-like haemoproteins satisfy this criterion; thus, both the soluble (Poole et al., 1984, 1986) and membrane-bound pigments (Lorence et al., 1986) in Escherichia coli are high-spin $b$-type haemoproteins and neither is an oxidase per se. The soluble species is a hydroperoxidase (Poole et al., 1986) as is a spectrally similar pigment in Bradyrhizobium japonicum (C. A. Appleby \& R. K. Poole, unpublished results), while the membrane-bound pigment is a constituent of the 
cytochrome $b d$ oxidase complex (Lorence et al., 1986) and functions in direct electron donation to cytochrome $d$ (Poole \& Williams, 1987). A similar function has been ascribed to the cytochrome $a_{1}$-like pigment of Acetobacter pasteurianus NCIB 6428 (Williams \& Poole, 1987).

We have investigated the occurrence and role of an $a_{1}$ like cytochrome in Comamonas percolans (NCTC 1937), a Gram-negative bacterium of uncertain taxonomic affiliation. It was originally considered to be a Vibrio sp. but later work proposed this strain of $C$. percolans to be the type species of the genus Comamonas (Davies \& Park, 1962), whereas Stanier et al. (1966) included Comamonas among the aerobic pseudomonads. This study on the cytochromes of $C$. percolans was prompted by a taxonomic survey (Spicher, 1974) of numerous genera, which included a number of representatives of Comamonas. Cytochrome a-like pigments were evident in each, although the $\alpha$-absorption maxima (reduced minus oxidized) varied from 595 to $603 \mathrm{~nm}$. In view of the few bacteria now thought to contain true cytochromes $a_{1}$, strain NCTC 1937, which exhibited a peak at $595 \mathrm{~nm}$, was selected for study. Here we report the occurrence of cytochrome $a a_{3}$ in aerobically grown, oxygen-sufficient cells and demonstrate its oxidase role using lowtemperature ligand-exchange techniques. A cytochrome $a_{1}$-like haemoprotein, of uncertain function, was found in cells from oxygen-limited cultures.

\section{Methods}

Organism, growth and preparation of subcellular fractions. Comamonas percolans NCTC 1937 was obtained from the National Collection of Type Cultures (Central Public Health Laboratories, London, UK) and grown on nutrient agar (NA) and nutrient broth (NB) made up as recommended by the manufacturers (Oxoid). The organism was maintained on NA slopes and subcultured every few weeks.

Starter cultures for $\mathrm{O}_{2}$-sufficient growth were prepared by washing cells from a NA slope into $25 \mathrm{ml}$ of NB in a $250 \mathrm{ml}$ conical flask and shaking (200 r.p.m.) for 8 to $10 \mathrm{~h}$ at $30^{\circ} \mathrm{C}$. This culture was then used to inoculate 10 litres of NB medium in a 12 litre Biostat $\mathrm{V}$ fermenter (FT Scientific), sparged with air at 10 litres $\mathrm{min}^{-1}$, and stirred vigorously. A small amount of antifoam (about $5 \mathrm{ml}$ ) was added to prevent excessive foaming. The culture was harvested after about $450 \mathrm{~min}$, when the $\mathrm{OD}_{600}$ was about $1 \cdot 0$, measured (after diluting $1: 10$ with water) against a water blank in $1 \mathrm{~cm}$ pathlength cuvettes using a Pye-Unicam SP-450 spectrophotometer.

For $\mathrm{O}_{2}$-limited growth, a slope culture was used to inoculate $200 \mathrm{ml}$ of medium in a $250 \mathrm{ml}$ conical flask and the culture was grown at $30^{\circ} \mathrm{C}$ without shaking for 20 to $24 \mathrm{~h}$. This was used to inoculate 20 litres of medium, and the culture was stirred slowly and sparged with air at 2 litres min $^{-1}$. The culture was harvested after 20 to $24 \mathrm{~h}$ when the $\mathrm{OD}_{600}$ was 0.4 to 0.5 .

Cells were harvested using an Alpha-Laval continuous-action centrifuge, resuspended in $50 \mathrm{~mm}$-potassium phosphate buffer $(\mathrm{pH} 7.0)$ and centrifuged at $15000 \mathrm{~g}$ for 10 to $15 \mathrm{~min}$. The cells were then washed and resuspended in the same buffer and recentrifuged. If necessary, cells were stored at $-20^{\circ} \mathrm{C}$ until needed.

To prepare subcellular fractions, harvested and washed cells were resuspended in $50 \mathrm{mM}$-potassium phosphate buffer $(\mathrm{pH} \mathrm{7.0)}$ at $1 \mathrm{~g}$ wet weight $\mathrm{ml}^{-1}$ and a few grains of DNAase added. The cells were disrupted by ultrasonication using an MSE $150 \mathrm{~W}$ sonicator (probe end diameter $9.5 \mathrm{~mm}$ ) for five periods of $30 \mathrm{~s}$ each, separated by $15 \mathrm{~s}$ intervals. The sample in the sonicator vessel was surrounded by an icesalt slurry to aid cooling. The suspension was centrifuged at $12000 \mathrm{~g}$ for $15 \mathrm{~min}$ to leave a cell-free extract $\left(\mathrm{S}_{0}\right)$, which was further fractionated (Poole \& Haddock, 1974) by centrifugation at $225000 \mathrm{~g}$ for $60 \mathrm{~min}$ to yield a 'high-speed supernatant' $\left(S_{1}\right)$ and membrane pellet $\left(P_{1}\right)$. The latter was homogenized in buffer and recentrifuged at $225000 \mathrm{~g}$ for $60 \mathrm{~min}$ to give a washed pellet $\left(\mathrm{P}_{2}\right)$ and second supernatant $\left(\mathrm{S}_{2}\right)$. Fractions were stored at $-20^{\circ} \mathrm{C}$ until needed.

Spectrophotometry. Washed cells were resuspended in buffer to a protein concentration of approximately $15 \mathrm{mg} \mathrm{ml}^{-1}$. Room-temperature difference spectra (reduced minus oxidized and reduced $+\mathrm{CO}$ minus reduced) were recorded using a Johnson Foundation DBS-3 dualwavelength scanning spectrophotometer as described previously (Williams \& Poole, 1987). Samples were reduced with a few grains $(\leqslant 5 \mathrm{mg})$ of sodium dithionite and oxidized in the presence of a small amount $(\leqslant 5 \mathrm{mg})$ of ammonium persulphate.

For low-temperature ligand-exchange studies the procedure of Williams \& Poole (1987) was followed, but photolysis of the COliganded, reduced oxidases was achieved by $30 \mathrm{~s}$ exposure to 'white' light from a $150 \mathrm{~W}$ projector lamp, focused by a lens on to the afferent limb of a bifurcated light-guide leading to the cuvette surface.

Haem extraction and pyridine haemochrome spectra of extracted haems. Haem extraction of membranes prepared from $\mathrm{O}_{2}$-sufficient and $\mathrm{O}_{2}$ limited cells was based on the method of Poole et al. (1984). Membranes prepared from a minimum of $18 \mathrm{~g}$ of cells were resuspended in $15 \mathrm{ml}$ of ice-cold acetone/water $(4: 1, \mathrm{v} / \mathrm{v})$ by hand homogenization and stirred vigorously for $15 \mathrm{~min}$. The membranes were recovered by filtering the suspension through $0.25 \mu \mathrm{m}$ nylon filters (Ultipore N66) under vacuum. The membranes were next stirred in $25 \mathrm{ml}$ of chloroform for $20 \mathrm{~min}$ at room temperature and the chloroform decanted. Then, $15 \mathrm{ml}$ of chloroform/pyridine $(2: 1, \mathrm{v} / \mathrm{v})$ was added and the mixture stirred for $90 \mathrm{~min}$ in the dark. The resulting haem extract was decanted and filtered as above to remove any lipid. Haem extracts from membranes of $\mathrm{O}_{2}$-sufficient cells were yellow in colour, while those from membranes of $\mathrm{O}_{2}$-limited cells were pink. These extracts were used directly for spectral analysis after adding an equal volume of $0.15 \mathrm{M}$ $\mathrm{NaOH}$. Samples were reduced with sodium dithionite $\left(<3 \mathrm{mg} \mathrm{ml}^{-1}\right)$ and oxidized with a few grains ( $\leqslant 5 \mathrm{mg}$ ) of ammonium persulphate.

Measurement of $\mathrm{O}_{2}$ uptake and $\mathrm{KCN}$ titrations. These were determined polarographically with a Clark-type oxygen electrode (Rank Bros., Bottisham, Cambridge, UK) as described by Poole (1977). Samples $(3 \mathrm{ml})$ of membranes resuspended in $50 \mathrm{mM}$-potassium phosphate buffer $(\mathrm{pH} 7.0)$ (protein concentration approximately $1 \mathrm{mg} \mathrm{ml}^{-1}$ ), were transferred to the electrode vessel at $30^{\circ} \mathrm{C}$, the lid of the vessel was replaced, substrate was added to a final concentration of $1 \mathrm{mM}$, and a recording of $\mathrm{O}_{2}$-tension was obtained. The electrode was calibrated using $\mathrm{O}_{2}$-saturated water at $30^{\circ} \mathrm{C}\left(240 \mathrm{nmol} \mathrm{O}_{2} \mathrm{ml}^{-1}\right)$ and then making it anoxic using a few grains $(\leqslant 5 \mathrm{mg}$ ) of sodium dithionite. The effect of $\mathrm{KCN}$ on $\mathrm{O}_{2}$ uptake was investigated by adding suitable amounts of freshly prepared KCN solution ( $\mathrm{pH} \mathrm{7.5} \mathrm{to} \mathrm{8.5)} 3$ to $5 \mathrm{~min}$ after addition of sodium succinate, when a linear rate of respiration had been attained. The effect of cyanide was virtually instantaneous. Inhibition is expressed as a percentage of the uninhibited rate in the same trace.

Protein. This was assayed by the method of Markwell et al. (1978).

Chemicals. General reagents were from BDH, Fisons or Sigma, and were of AnalaR grade wherever possible. $\mathrm{CO}$ was from BOC Special Gases. 

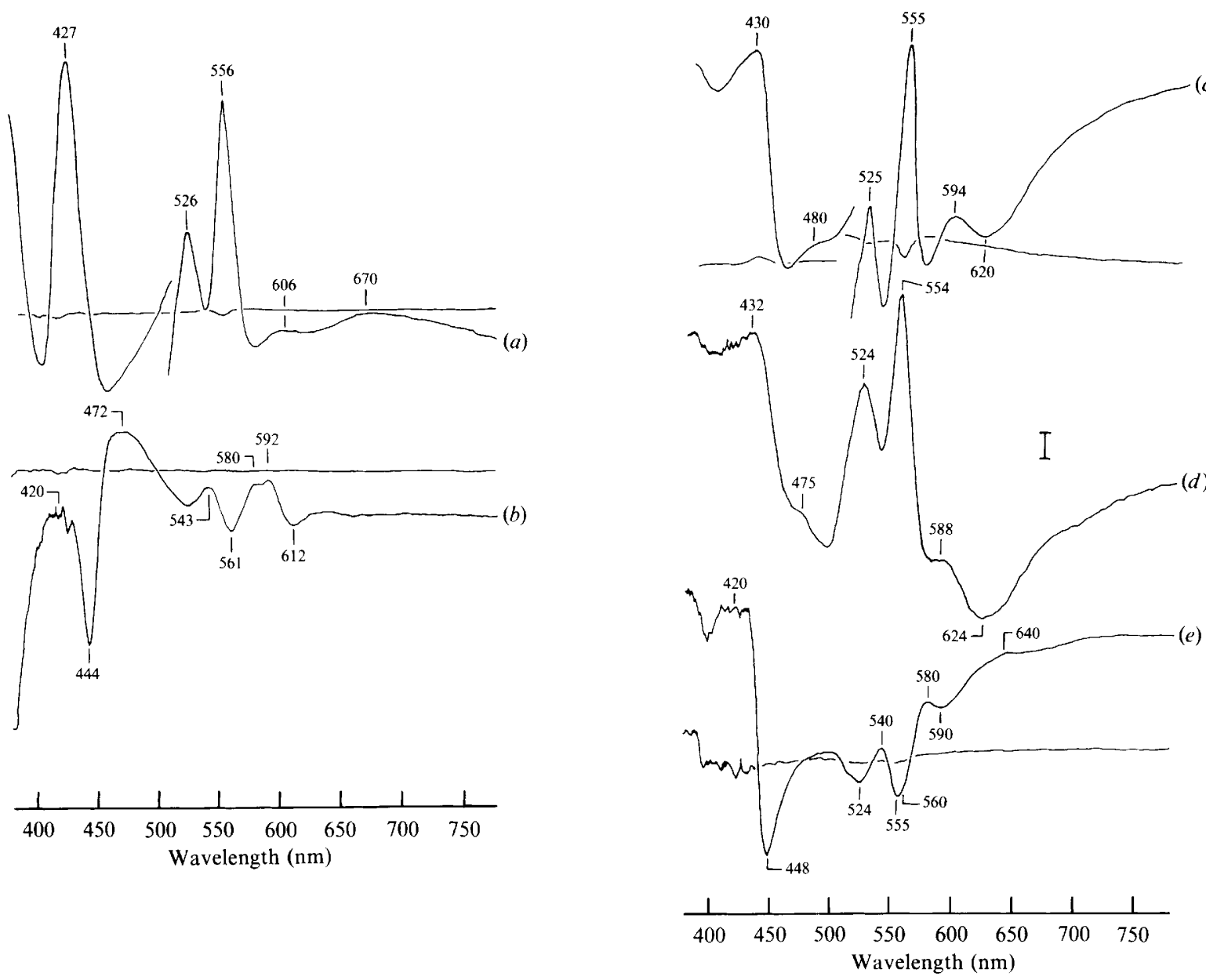

Fig. 1. Difference spectra, recorded at room temperature, of intact cells of $C$. percolans grown under $\mathrm{O}_{2}$-sufficient $(a, b)$ or $\mathrm{O}_{2}$-limited $(c, d, e)$ conditions. $(a),(c)$ and $(d)$ are reduced (dithionite) minus oxidized (persulphate) spectra; $(b)$ and $(e)$ are reduced $+\mathrm{CO}$ minus reduced difference spectra. Unlabelled spectra are baselines, oxidized minus oxidized or reduced minus reduced as appropriate. Spectra were recorded at $5.7 \mathrm{~nm} \mathrm{~s}^{-1}$, a spectral bandwidth of $8 \mathrm{~nm}$ and a reference wavelength of $500 \mathrm{~nm}$ (in the dual-wavelength mode). The vertical bar represents, from 380 to $500 \mathrm{~nm}, \Delta A 0.04(a, d)$ or $0.02(b, c, e)$ and, from above $500 \mathrm{~nm}, 0.01(a, b)$ or $0.02(c, d, e)$.

\section{Results}

Cytochrome composition of C. percolans NCTC 1937 following $\mathrm{O}_{2}$-sufficient and $\mathrm{O}_{2}$-limited growth

The reduced minus oxidized difference spectrum of intact cells of $C$. percolans grown with vigorous aeration $[11$ air $\left.\min ^{-1}(1 \text { of culture })^{-1}\right]$ is shown in Fig. $1(a)$. There was a broad $\alpha$-maximum at $556 \mathrm{~nm}$, probably due mainly to $b$ type cytochrome(s), and a peak at $606 \mathrm{~nm}$, suggesting the presence of cytochrome $a a_{3}$. A weak shoulder at about $550 \mathrm{~nm}$ might indicate a low concentration of $c$-type cytochrome(s). Additionally, there was a broad absorbance centred at $670 \mathrm{~nm}$ due to an unknown chromophore. The presence of cytochrome $a a_{3}$ was confirmed by the CO-difference spectrum (Fig. $1 b$ ), which showed a maximum at $592 \mathrm{~nm}$, due to the CO-complex of haem $a_{3}$, and troughs at 444 and $612 \mathrm{~nm}$, resulting from the loss of the reduced $a_{3}$ on binding $\mathrm{CO}$. The maxima at 420,543 and $580 \mathrm{~nm}$, together with the asymmetric trough at $561 \mathrm{~nm}$ in the CO-difference spectrum, indicated one or more CO-binding cytochromes $b$ to be present.

Cells grown under $\mathrm{O}_{2}$-limited conditions $[0.11$ air $\min ^{-1}(1 \text { of medium })^{-1}$ ] were a deep red colour compared to the light brown colour of cells grown with vigorous aeration. The most striking spectral difference was the presence of an $\alpha$-maximum at 588 to $594 \mathrm{~nm}$ in reduced minus oxidized difference spectra (Fig. $1 c, d$ ). However, there was variation in the position of the $\alpha$-maximum and in the spectral shape of the signal even in two separately scanned samples from the same cell suspension and apparently treated in an identical fashion (Fig. 1c,d). This $\alpha$-maximum was always observed, in whole cells, in the region expected for a 'classical' cytochrome $a_{1}$. There was also a prominent trough at 620 to $624 \mathrm{~nm}$. The COdifference spectrum of $\mathrm{O}_{2}$-limited cells (Fig. $1 e$ ) had a minimum at $448 \mathrm{~nm}$ and a maximum at $420 \mathrm{~nm}$, 
probably attributable to the cytochrome $a_{1}$-like component. The $\alpha$-region differed from that observed in $\mathrm{O}_{2}$ sufficient cells (Fig. $1 b$ ), having a minimum at $590 \mathrm{~nm}$ and a broad maximum at $640 \mathrm{~nm}$. The spectrum also indicated the presence of at least one CO-binding cytochrome $b$ (minimum at 555 to $560 \mathrm{~nm}$ ). $\mathrm{O}_{2}$-limited cells had about twofold greater levels of cytochromes $b$ and $c$ on a protein basis, compared to $\mathrm{O}_{2}$-sufficient cells, possibly explaining the deep red appearance of the former.

\section{Subcellular distribution of cytochromes in $C$. percolans grown under $\mathrm{O}_{2}$-sufficient and $\mathrm{O}_{2}$-limited conditions}

Cell-free extracts $\left(\mathrm{S}_{0}\right)$ of $\mathrm{O}_{2}$-sufficient $C$. percolans had a similar cytochrome composition to whole cells (data not shown). Spectral analysis of high-speed supernatant $\left(\mathbf{S}_{1}\right)$ and washed membrane fractions $\left(\mathrm{P}_{2}\right)$ showed that the majority ( 73 to $89 \%$ ) of cytochrome $a a_{3}$ was present in the sedimentable membrane fraction $\left(\mathrm{P}_{2}\right)$. Also present in this fraction was a CO-binding cytochrome $b$ ( $\alpha$-trough at $562 \mathrm{~nm}$ ) whose spectrum suggested it was a low-spin cytochrome $b$ (Wood, 1984). However, in the high-speed supernatant $\left(\mathrm{S}_{1}\right)$ weak signals from a CO-binding cytochrome $b$ ( $\alpha$-maximum at $554 \mathrm{~nm}$ ) were observed, which spectrally resembled a high-spin cytochrome $b$ (data not shown).

A similar fractionation of $\mathrm{O}_{2}$-limited cells showed that the cytochrome $a_{1}$-like component was membraneassociated, as $>80 \%$ of it, when quantified using the $\alpha$ maximum in reduced minus oxidized spectra, was found in the sedimentable membrane fraction $\left(\mathrm{P}_{2}\right)$. The $\alpha$ maximum varied between 595 and $600 \mathrm{~nm}$ even in spectra from the same batch of membranes, although the $592 \mathrm{~nm}$ peak of an $a_{3}-\mathrm{CO}$ complex was never observed. CO-difference spectra of the membrane fraction indicated a high-spin CO-binding cytochrome $b$ to be present (minimum at $560 \mathrm{~nm}$ ). A second, soluble, high-spin CObinding cytochrome $b$ was detected in the high-speed supernatant fraction (minimum at $556 \mathrm{~nm}$ ) and spectrally resembled that found (in smaller amounts) in $\mathrm{O}_{2}$ sufficient cells (data not shown).

\section{Spectral changes in the 580 to $610 \mathrm{~nm}$ region of $\mathrm{O}_{2}$-limited cells}

As described above, the position of the $\alpha$-maximum of the $a_{1}$-like component of $\mathrm{O}_{2}$-limited cells varied from 590 to $600 \mathrm{~nm}$ in spectra of the same batch of cells or membranes. This was studied further in the reduced minus oxidized spectra shown in Fig. 2. Since the reduced spectrum was the same in each of the difference spectra plotted, any changes seen must have occurred in the

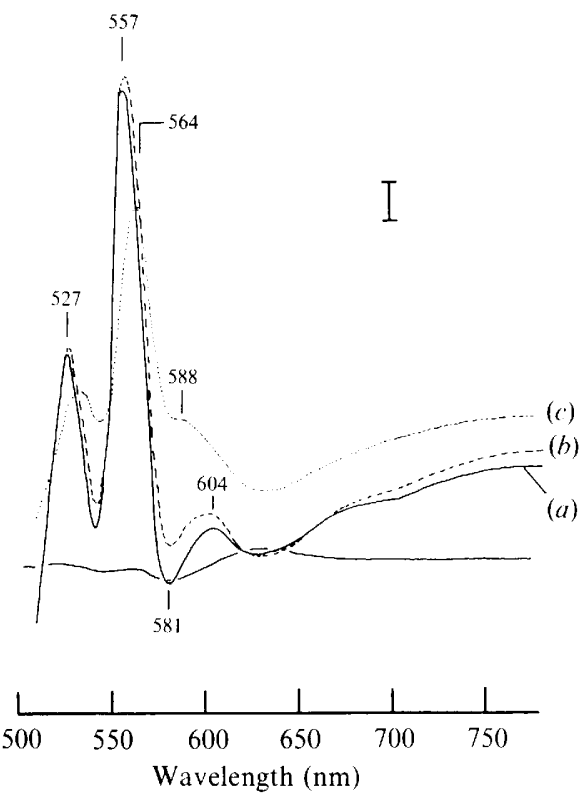

Fig. 2. Spectral changes in air-oxidized washed membranes $\left(\mathrm{P}_{2}\right)$ from $\mathrm{O}_{2}$-limited cells of $C$. percolans. A reduced (dithionite) suspension was scanned and stored in the digital memory of the dual-wavelength spectrophotometer. An air-oxidized sample was scanned and a reduced minus air-oxidized spectrum $(a)$ was plotted. The air-oxidized sample was scanned again after 3 min and a reduced minus oxidized spectrum (b) again plotted. This was repeated after a further 5 min to yield spectrum $(c)$. Note that the same original reduced spectrum was used for all the replotted difference spectra. The unlabelled spectrum is a reduced minus reduced baseline. Spectra were recorded at $5.7 \mathrm{~nm} \mathrm{~s}^{-1}$, a bandwidth of $8 \mathrm{~nm}$ and a reference wavelength of $500 \mathrm{~nm}$. The vertical bar represents a $\Delta A$ of $0 \cdot 04$.

oxidized suspension. In the first spectrum scanned after oxidizing the membrane suspension (Fig. $2 a$ ) there were maxima at 527, 557 and $604 \mathrm{~nm}$. After 3 min the suspension was rescanned and a second reduced minus oxidized spectrum plotted (Fig. $2 b$ ). There was a small decrease in the height of the $557 \mathrm{~nm}$ peak but the $\alpha$ maximum had shifted slightly to $602 \mathrm{~nm}$ and there was a small absorbance increase at $581 \mathrm{~nm}$. When the sample was rescanned after a further $5 \mathrm{~min}$, significant changes had occurred (Fig. 2c). The height of the $\alpha$ - and $\beta$ absorbance bands had decreased and shifted to 564 and $534 \mathrm{~nm}$, respectively, suggesting that a cytochrome $b$ absorbing at $557 \mathrm{~nm}$ had become reduced. The apparent absorbance maximum at $602 \mathrm{~nm}$ shifted to about $588 \mathrm{~nm}$, accompanied by a dramatic change in the shape of the band. No such changes were observed in membrane fractions from $\mathrm{O}_{2}$-sufficient cells (data not shown). Similar changes were observed in experiments on whole cells; the nature of these changes is at present not understood (see Discussion). 


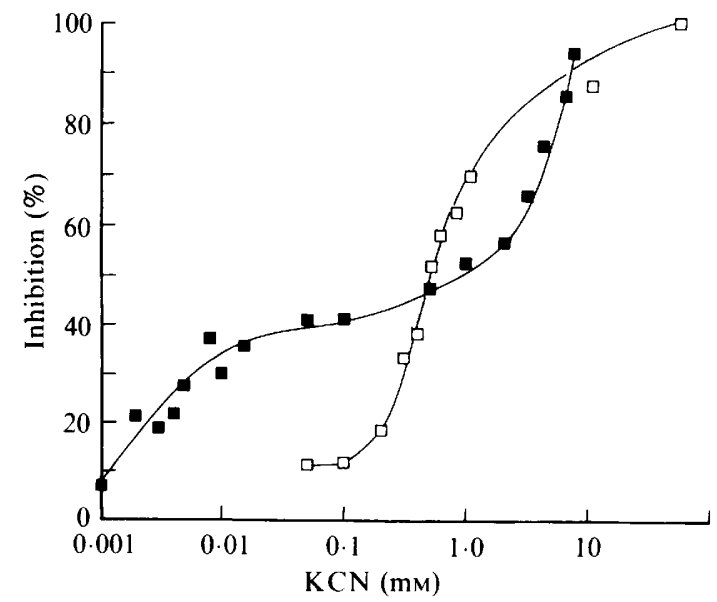

Fig. 3. Inhibitory effect of $\mathrm{KCN}$ on succinate oxidase activities in membranes of $C$. percolans grown under $\mathrm{O}_{2}$-sufficient $(\square)$ or $\mathrm{O}_{2}$ limited $(\boldsymbol{\square})$ conditions. Oxidase activity was measured polarographically as described in Methods, with $1 \mathrm{~mm}$-succinate as substrate.

\section{Pyridine haemochrome spectra of haems extracted from $\mathrm{O}_{2}$-sufficient and $\mathrm{O}_{2}$-limited $\mathrm{C}$. percolans}

Alkaline pyridine haemochrome spectra were recorded of haem extracts prepared from membranes of $\mathrm{O}_{2}$ sufficient and $\mathrm{O}_{2}$-limited C. percolans (not shown). The spectrum of the reduced pyridine haemochrome of membranes from $\mathrm{O}_{2}$-sufficient cells showed maxima at 422, 524, 556 and $588 \mathrm{~nm}$; similar maxima were observed in a reduced minus oxidized spectrum. The maximum at $588 \mathrm{~nm}$ suggested the presence of haem A (Fuhrop \& Smith, 1975), which presumably originated from the cytochrome $a a_{3}$ present in these cells. The $556 \mathrm{~nm}$ band indicates the presence of haem B. Haem C was not detected in these extracts.

Similar spectra of pyridine haemochromes of membranes from $\mathrm{O}_{2}$-limited cells showed the $556 \mathrm{~nm}$ band, consistent with the presence of haem $B$, but there was no band at $588 \mathrm{~nm}$, suggesting that haem $A$ was absent from $\mathrm{O}_{2}$-limited cells.

\section{Effect of $\mathrm{KCN}$ on $\mathrm{O}_{2}$ uptake by $C$. percolans membranes}

Membranes from $\mathrm{O}_{2}$-sufficient and $\mathrm{O}_{2}$-limited C. percolans were able to oxidize a variety of substrates. The oxidation rates $\left[\mathrm{nmol} \mathrm{O}_{2} \mathrm{~min}^{-1}\right.$ (mg protein) $\left.{ }^{-1}\right]$ for cells from $\mathrm{O}_{2}$-sufficient and $\mathrm{O}_{2}$-limited cultures, respectively, were: NADH, 79, 50; sodium succinate 98,51 ; sodium lactate $20,62 . \alpha$-Glycerophosphate was oxidized, slowly [12 $\mathrm{nmol} \mathrm{O}_{2} \min ^{-1}(\mathrm{mg} \text { protein) })^{-1}$, only by membranes prepared from $\mathrm{O}_{2}$-sufficient cells. Fig. 3 shows the effects of $\mathrm{KCN}$ on the succinate oxidase activities of membranes from $\mathrm{O}_{2}$-sufficient and $\mathrm{O}_{2}$-limited cells. Mem- branes from $\mathrm{O}_{2}$-sufficient cells exhibited a monophasic inhibition curve, indicating only one site of inhibition, with $50 \%$ inhibition occurring at about $500 \mu \mathrm{M}-\mathrm{KCN}$. In contrast, the $\mathrm{KCN}$ inhibition curve of succinate oxidase activity in membranes from $\mathrm{O}_{2}$-limited cells was biphasic, indicating two inhibition sites, with $50 \%$ inhibition occurring at about $2.5 \mu \mathrm{M}$ and about $3.5 \mathrm{~mm}$, respectively. This suggests that there are two $\mathrm{KCN}$-sensitive oxidases functioning under $\mathrm{O}_{2}$-limiting conditions, which are distinct from the single oxidase present in membranes from $\mathrm{O}_{2}$-sufficient cells.

\section{Reaction with $\mathrm{CO}$ and $\mathrm{O}_{2}$ of cytochromes in $\mathrm{O}_{2}$-sufficient cells}

The reaction of potential cytochrome oxidases, in $\mathrm{O}_{2}$ sufficient cells, with $\mathrm{CO}$ and $\mathrm{O}_{2}$ was investigated using low-temperature photolysis procedures (Chance et al., 1975; Williams \& Poole, 1987). When an endogenously reduced, $\mathrm{CO}$-saturated cell suspension was photolysed in the absence of $\mathrm{O}_{2}$ with the focused beam from a $150 \mathrm{~W}$ projector lamp for $30 \mathrm{~s}$ at $-128^{\circ} \mathrm{C}$, the resulting (postphotolysis minus pre-photolysis) photodissociation spectrum showed the features of a pure cytochrome $a a_{3}$ photodissociation spectrum (Fig. $4 a$ ). There were absorbance maxima at 448 and $615 \mathrm{~nm}$, due to the appearance of reduced cytochrome $a_{3}$ in the sample, and minima at 430 and $592 \mathrm{~nm}$, due to the loss of CO-liganded cytochrome $a_{3}$ from the sample (Poole et al., 1979a; Wikström et al., 1981; Sone et al., 1984). No changes occurred upon repetitive scanning at this temperature. There were no signals, in the Soret or $\alpha$-regions, of the spectrum attributable to photodissociation of cytochrome o (Poole et al., 1979b; De Maio et al., 1983; Williams \& Poole, 1988) despite the presence in these cells of CO-binding cytochrome $b$ (Fig. $1 b$ ). When photolysis was performed at higher temperatures (for example, $-87^{\circ} \mathrm{C}$ : Fig. $4 b$ ), recombination of $\mathrm{CO}$ to haem $a_{3}$ occurred (Fig. $4 c$ ). Rephotolysis of the sample to which $\mathrm{CO}$ had recombined reformed the original spectrum (data not shown). The kinetics of COrecombination to haem $a_{3}$ were biphasic when analysed as semi-logarithmic plots (not shown) but measurements of the pseudo-first-order velocity constant for the initial fast phase, over the temperature range -103 to $-78^{\circ} \mathrm{C}$, allowed construction of an Arrhenius plot from which an activation energy of $36.4 \mathrm{~kJ} \mathrm{~mol}^{-1}$ was obtained. This value is similar to that for cytochrome $a_{3}$ in bovine heart (35.1 kJ mol ${ }^{-1}$; Ereckinska \& Chance, 1972), Schizosaccharomyces pombe $\left(28.9 \mathrm{~kJ} \mathrm{~mol}^{-1}\right.$; Poole et al., 1979a) and the thermophilic bacterium PS3 $\left(29.3 \mathrm{~kJ} \mathrm{~mol}^{-1}\right.$; Sone et al., 1984).

The reaction with $\mathrm{O}_{2}$ was studied after supplementing the cell sample with $\mathrm{O}_{2}$ prior to freezing. Spectral 

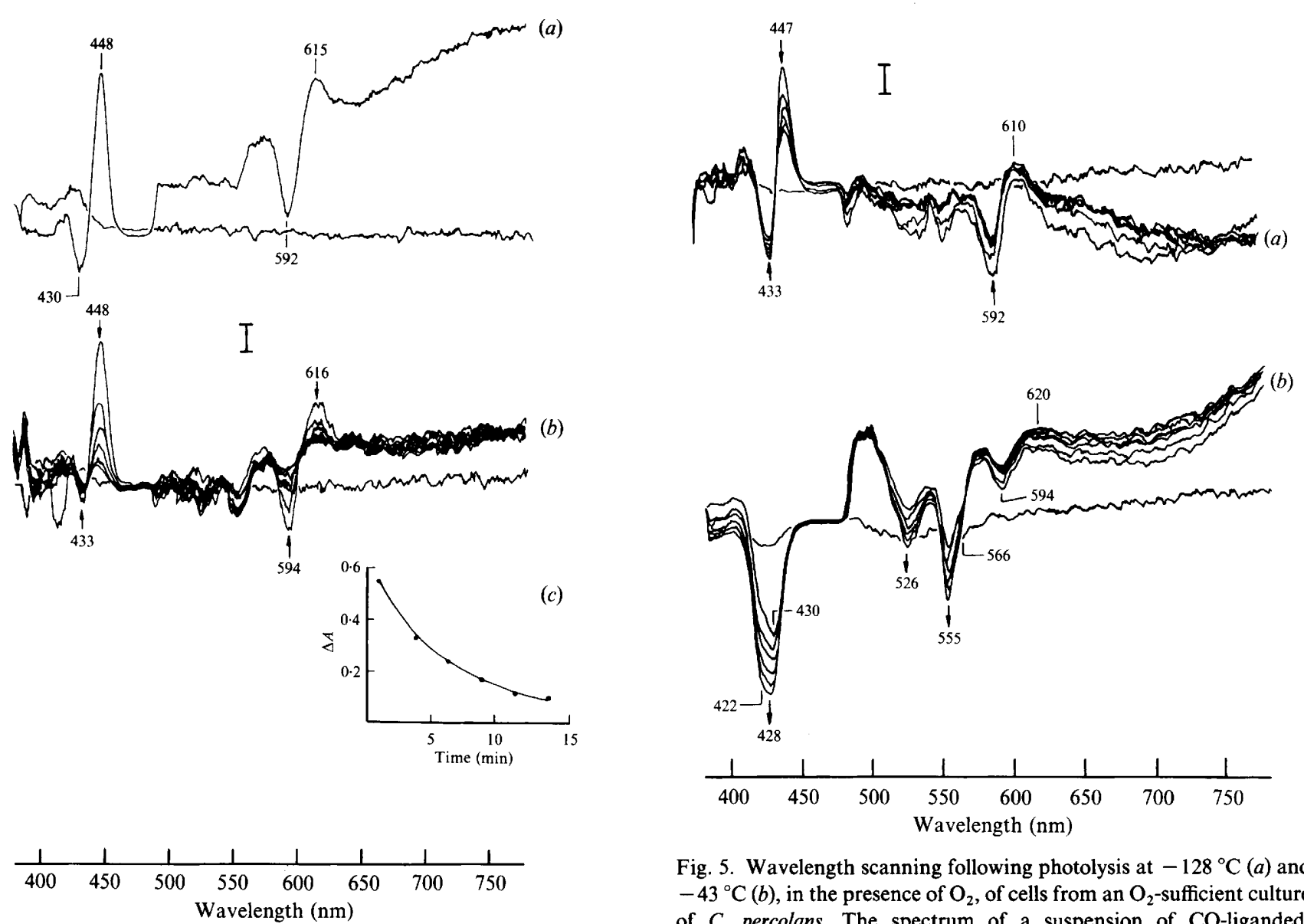

Fig. 4. Wavelength scanning following photolysis at $-128^{\circ} \mathrm{C}(a)$ and $-87^{\circ} \mathrm{C}(b, c)$, in the absence of $\mathrm{O}_{2}$, of intact cells from an $\mathrm{O}_{2}$-sufficient culture of $C$. percolans. The spectrum of CO-liganded, endogenously reduced cells was scanned and stored. In $(a)$ and $(b)$ the flat featureless spectrum represents the reduced $+\mathrm{CO}$ minus reduced $+\mathrm{CO}$ spectrum recorded before photolysis. Each sample was then photolysed at $-128^{\circ} \mathrm{C}(a)$ or $-87^{\circ} \mathrm{C}(b, c)$ by a $30 \mathrm{~s}$ exposure to white light from a $150 \mathrm{~W}$ lamp and scanned. Arrows at prominent wavelengths show the direction of changes in repetitive scans $(b)$. The scan speed was $2.86 \mathrm{~nm} \mathrm{~s}^{-1}$, the spectral bandwidth $8 \mathrm{~nm}$, and the reference wavelength $500 \mathrm{~nm}$. The vertical bar represents a $\Delta A$ of 0.01 up to $500 \mathrm{~nm}$ and 0.004 above $500 \mathrm{~nm}$. The change in absorbance at $448 \mathrm{~nm}$ minus $470 \mathrm{~nm}$ following photolysis is shown in $(c)$.

changes after photodissociation of $\mathrm{CO}$ from the cytochrome $a_{3}-\mathrm{CO}$ complex in the presence of $\mathrm{O}_{2}$ at $-128^{\circ} \mathrm{C}$ are shown in Fig. $5(a)$. The initial spectrum after photolysis was similar to that observed in the absence of $\mathrm{O}_{2}$ (Fig. $4 a$ ) except that the Soret trough at $433 \mathrm{~nm}$ was deeper, the $\alpha$-signals had a lower extinction and the $\alpha$-maximum due to $a_{3}$ was at a shorter wavelength $(610 \mathrm{~nm})$. However, upon repetitive scanning, the Soret features approached the baseline (the spectrum of the CO-liganded enzyme), indicative of

Fig. 5. Wavelength scanning following photolysis at $-128^{\circ} \mathrm{C}(a)$ and $-43^{\circ} \mathrm{C}(b)$, in the presence of $\mathrm{O}_{2}$, of cells from an $\mathrm{O}_{2}$-sufficient culture of $C$. percolans. The spectrum of a suspension of $\mathrm{CO}$-liganded, endogenously reduced cells, to which $\mathrm{O}_{2}$ had been added at $-23^{\circ} \mathrm{C}$ by stirring, was scanned at $-128^{\circ} \mathrm{C}$ and stored. Subtraction of this from the subsequent scan of the unphotolysed sample gave the reduced $+\mathrm{CO}$ minus reduced $+\mathrm{CO}$ baseline. The sample was photolysed at $-128^{\circ} \mathrm{C}$ by $30 \mathrm{~s}$ exposure to white light from a $150 \mathrm{~W}$ lamp and repetitively scanned $(a)$. Scanning was initiated at $89 \mathrm{~s}$ intervals. In (b) the procedure was identical but the sample was photolysed and its spectrum recorded at $-43^{\circ} \mathrm{C}$. Other conditions were as in Fig. 4. The vertical bar represents, up to $500 \mathrm{~nm}$, a $\Delta A$ of 0.01 in (a) and 0.02 (in $b$ ) and, above $500 \mathrm{~nm}$, a $\Delta A$ of $0.002(a, b)$.

ligand-binding. The non-photodissociability of the complex thus formed (data not shown) suggested that the ligand was $\mathrm{O}_{2}$, not $\mathrm{CO}$. The velocity of ligand binding was greater in the presence of $\mathrm{O}_{2}$; for example, at $-103^{\circ} \mathrm{C}$ the pseudo-first-order velocity constant was $0.135 \mathrm{~min}^{-1}$ in the presence of $\mathrm{O}_{2}$ and $0.019 \mathrm{~min}^{-1}$ in its absence. When the kinetics of oxygen binding were analysed in semi-logarithmic plots (not shown) a biphasic pattern was obtained; measurements of the rates of the initial fast phase of $\mathrm{O}_{2}$-binding, over the temperature range $-128^{\circ} \mathrm{C}$ to $-92^{\circ} \mathrm{C}$, gave an activation energy of $4.76 \mathrm{~kJ} \mathrm{~mol}^{-1}$ for the $\mathrm{O}_{2}$-binding reaction. The initial change in the $\alpha$-region at $-128^{\circ} \mathrm{C}$ following photolysis 
was an increase in absorbance at $592 \mathrm{~nm}$ and a small decrease at $610 \mathrm{~nm}$. No changes were observed after the third scan. At $-103{ }^{\circ} \mathrm{C}$, further reactions occurred (not shown). $\mathrm{O}_{2}$-binding was faster and minima started to form at $530 \mathrm{~nm}$ and at $554 \mathrm{~nm}$, shifting in later scans to $568 \mathrm{~nm}$. These changes suggested the further reaction of cytochrome $a a_{3}$ and the oxidation of $b / c$-type cytochromes. At $-92^{\circ} \mathrm{C}$, the $448 \mathrm{~nm}$ maximum had disappeared by the first scan and this was accompanied by oxidation of a $b$-type cytochrome at $567 \mathrm{~nm}$, while at $-43^{\circ} \mathrm{C}$ (Fig. $5 b$ ) oxidation of a third cytochrome $b$, at $555 \mathrm{~nm}$, was seen, concomitant with decreases in absorbance in the Soret region. Little change was seen in the $\alpha$-signals of cytochrome $a a_{3}$ at these higher temperatures except that the prominent $610 \mathrm{~nm}$ maximum disappeared and this was accompanied by a decrease in absorbance at $594 \mathrm{~nm}$. The changes indicated that electron-transfer to cytochrome $a a_{3}$ had occurred with oxidation of $b / c$-type cytochromes.

\section{Reactions with $\mathrm{CO}$ and $\mathrm{O}_{2}$ of haemoproteins in $\mathrm{O}_{2}$-limited cells}

The unusual and variable cytochrome spectra of cells from $\mathrm{O}_{2}$-limited cultures (see Fig. $1 c$ to $e$ and Fig. 2) prompted an attempt to identify a ligand-binding component that could be identified as a putative terminal oxidase on low-temperature photodissociation of intact cells. Such low-temperature spectra, however, like room-temperature spectra, were variable in form. In the absence of $\mathrm{O}_{2}$ in the cuvette the simplest photodissociation difference spectrum recorded (Fig. $6 a$ ) exhibited a peak at $448 \mathrm{~nm}$ and a weak trough at $590 \mathrm{~nm}$. These features might conventionally be attributed to photolysis of the CO compound of an $a$-type cytochrome (e.g. Fig. $4 a, b)$ but alkaline pyridine haemochrome spectra of extracted haems failed to show haem A. An alternative candidate is a $b$-590-like haemoprotein, i.e. a high-spin, haem-B-containing protein and, indeed, $\mathrm{CO}$ difference spectra (Fig. 1e) showed the presence of such a component. At $-83^{\circ} \mathrm{C}$ (not shown), light-reversible ligand recombination was suggested by diminution of the $448 \mathrm{~nm}$ peak, indicative of reaction with $\mathrm{CO}$. The kinetics of $\mathrm{CO}$ recombination were biphasic; the pseudofirst-order velocity constant for the initial fast phase was $0.074 \mathrm{~min}^{-1}$, approximately fivefold slower than that of $\mathrm{CO}$ recombination to cytochrome $a_{3}$ at this temperature (see above). In other photodissociation spectra at $-102{ }^{\circ} \mathrm{C}$ in the absence of $\mathrm{O}_{2}$ (not shown), additional absorption maxima at 421, 524 and $552 \mathrm{~nm}$, of unknown origin, were observed, perhaps arising from photodissociable CO compounds of $b$ - and/or $c$-type cytochromes.

The corresponding photodissociation spectrum at $-102{ }^{\circ} \mathrm{C}$ of cells in the presence of $\mathrm{O}_{2}$ (Fig. $6 b$ ) revealed
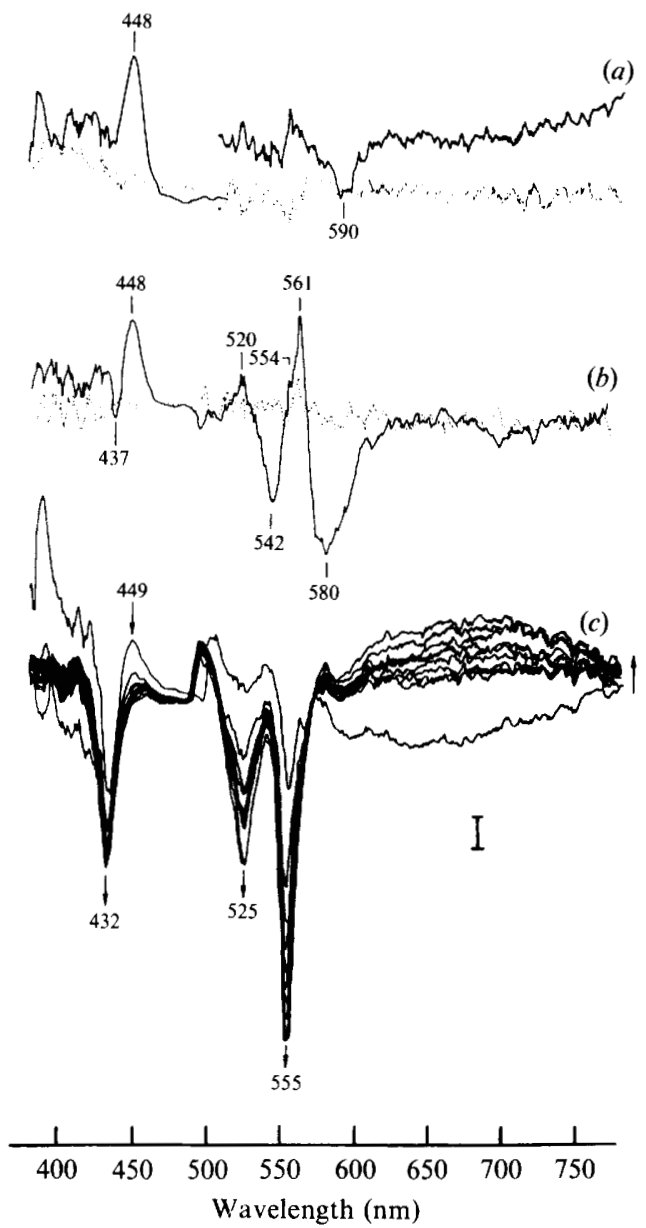

Fig. 6. Photolysis and wavelength scanning of CO-treated cells from $\mathrm{O}_{2}$-limited cultures in the absence of $\mathrm{O}_{2}$ at $-102^{\circ} \mathrm{C}(a)$, and in the presence of $\mathrm{O}_{2}$ at $-102^{\circ} \mathrm{C}(\mathrm{b})$ and $-69^{\circ} \mathrm{C}(\mathrm{c})$. The spectrum of a COliganded, endogenously reduced and either anoxic $(a)$ or $\mathrm{O}_{2^{-}}$ supplemented $(b, c)$ cell suspension was scanned and stored in the digital memory of the dual-wavelength spectrophotometer. In each case the flat featureless spectrum represents the reduced $+\mathrm{CO}$ minus reduced $+\mathrm{CO}$ spectrum recorded before photolysis. Each sample was then photolysed at $-102^{\circ} \mathrm{C}(a, b)$ or $-69^{\circ} \mathrm{C}(c)$ by a $30 \mathrm{~s}$ exposure to white light from a $150 \mathrm{~W}$ lamp, and scanned. The scan speed was $2.86 \mathrm{~nm} \mathrm{~s}^{-1}$, the spectral bandwidth $8 \mathrm{~nm}$ and the reference wavelength $500 \mathrm{~nm}$. In (a) the vertical bar represents a $\Delta A$ of 0.01 or 0.02 below and above $500 \mathrm{~nm}$, respectively. In $(c)$ spectral scanning was initiated at $80 \mathrm{~s}$ intervals.

again a prominent $448 \mathrm{~nm}$ peak, only partially light sensitive at both -102 and $-69^{\circ} \mathrm{C}$. This suggests that the recombining ligand was $\mathrm{CO}$, not $\mathrm{O}_{2}$. Following photolysis in the presence of $\mathrm{O}_{2}$ at $-69^{\circ} \mathrm{C}$ (Fig. $6 c$ ), the small $449 \mathrm{~nm}$ peak disappeared within two scans, concomitant with large decreases in absorbance at 432 , 525 and $555 \mathrm{~nm}$, indicative of oxidation of $b$ - and/or $c$-type cytochromes. 


\section{Discussion}

The aim of this work was to investigate the occurrence of cytochrome $a_{1}$ in C. percolans and to study its role in the respiratory chain. Spectral analysis of cells from highly aerated cultures demonstrated the presence of cytochrome $a a_{3}(\alpha$-maximum at $\sim 606 \mathrm{~nm}$ in reduced minus oxidized spectra) but not cytochrome $a_{1}$. However, when grown under $\mathrm{O}_{2}$-limited conditions, $C$. percolans lacked cytochrome $a a_{3}$ but had an $\alpha$-maximum at approximately $595 \mathrm{~nm}$, indicating the presence of a cytochrome $a_{1}$. COdifference spectra demonstrated its ability to bind $\mathrm{CO}$ and justified its consideration as a putative terminal oxidase. The variable position of the $\alpha$-absorption band, and recent information on the cytochrome $a_{1}$-like haemoproteins of E. coli (Poole et al., 1986; Lorence et al., 1986), Acetobacter pasteurianus (Williams \& Poole, 1987) and Halobacterium halobium (Fukomori et al., 1985) that demonstrate some so-called cytochrome $a_{1}$ like haemoproteins to contain high-spin haem $b$, led us to study this pigment further.

Cytochrome $a a_{3}$ of $\mathrm{O}_{2}$-sufficient cells was mainly membrane-associated. Some $a_{1}$-like haemoproteins have been shown to be soluble hydroperoxidases (Poole et al., 1986; Fukomori et al., 1985). However, most ( $>80 \%$ ) of the cytochrome $a_{1}$-like pigment of $C$.percolans was found in the membrane fraction.

Photochemical action spectroscopy of some strains of A. pasteurianus suggested that cytochrome $a_{1}$ was the sole cytochrome oxidase (Castor \& Chance, 1959). However, recent studies, albeit on a strain containing cytochrome oxidases $o$ and $d$ and a cytochrome $a_{1}$-like pigment, demonstrated the role of the latter in direct electrontransfer to cytochrome $d$ in its reaction with $\mathrm{O}_{2}$ (Williams \& Poole, 1986, 1987). Spectral analysis of pyridine haemochromes formed from haems extracted from membranes of $\mathrm{O}_{2}$-limited $C$. percolans failed to demonstrate the presence of haem $A$, precluding description of the $a_{1}$-like pigment as a true cytochrome $a_{1}$ (Poole et al., 1985). The same method showed haem A in the cytochrome $a a_{3}$-containing membranes of $\mathrm{O}_{2}$ sufficient cells. The $a_{1}$-like cytochrome present in membranes of $\mathrm{O}_{2}$-limited $C$. percolans is probably a highspin haem- $b$-containing pigment and can tentatively be called a cytochrome $b-595$. We obtained no evidence for the presence of cytochrome $d$, with which cytochrome $b$ 595 is associated in an oxidase complex in E. coli (Poole, 1988).

The simplest interpretation of the inhibition by $\mathrm{KCN}$ in membranes from $\mathrm{O}_{2}$-sufficient cells of $C$. percolans is that a single $\mathrm{KCN}$-sensitive oxidase is responsible for all the succinate-dependent $\mathrm{O}_{2}$ uptake. However, the presence of several oxidases with similar $\mathrm{KCN}$ sensitivities cannot be excluded. In contrast, membranes from
$\mathrm{O}_{2}$-limited cells showed a biphasic $\mathrm{KCN}$-titration curve, indicating the presence of at least two $\mathrm{KCN}$-sensitive oxidases. We detected no cyanide-resistant respiration such as is found in Pseudomonas aeruginosa (Matsushita et al., 1983).

Photolysis at low temperature of $\mathrm{O}_{2}$-limited cells was inconclusive in determining whether or not the presumptive cytochrome $b-595$ was functioning as a terminal oxidase. Nevertheless, following photodissociation in the absence of $\mathrm{O}_{2}$, a component was consistently observed with a maximum at about $448 \mathrm{~nm}$ and a trough at $590 \mathrm{~nm}$ which is probably due to photodissociation of cytochrome $b-595$. The variable appearance of additional signals possibly attributable to photodissociation of $b$ - or $c$-type cytochromes is not understood. Photodissociation in the presence of $\mathrm{O}_{2}$ did not show conclusively $\mathrm{O}_{2}$-binding to cytochrome $b$-595 as it was possible to, at least partially, reverse ligand binding by rephotolysis in the presence of $\mathrm{O}_{2}$, indicating that the major recombining ligand to cytochrome $b-595$ is $\mathrm{CO}$ and not $\mathrm{O}_{2}$. However, there was no direct evidence for $\mathrm{O}_{2}$-binding to any other components in $\mathrm{O}_{2}$-limited cells over the temperature range studied (down to $-150^{\circ} \mathrm{C}$ ), despite the presence of a number of $\mathrm{CO}$-binding cytochromes in the cells, and so the pigment with an absorbance band at $449 \mathrm{~nm}$ remains a likely candidate for one of the two oxidases suggested by the $\mathrm{KCN}$ titrations. At higher temperatures $\left(-69^{\circ} \mathrm{C}\right)$ photolysis-dependent oxidation of $b$ - and $c$-type cytochromes was seen, indicating that electron-transfer to $\mathrm{O}_{2}$ was occurring via a $\mathrm{CO}$-inhibited terminal oxidase. A possible reason for the inability to detect a second oxidase is that upon photolysis the presumptive oxidase(s) bind(s) ligands $\left(\mathrm{CO}\right.$ and $\left.\mathrm{O}_{2}\right)$ too rapidly to be observed and that the $\mathrm{O}_{2}$-liganded form is spectrally indistinguishable from the $\mathrm{CO}$-complex. Cytochrome $d$ provides a precedent for this behaviour; ligand binding after photolysis of the $\mathrm{CO}$ form is observed only at liquid helium temperatures (Poole et al., 1982).

The results presented in this paper provide another example of a bacterium modifying its respiratory chain composition, and in particular its cytochrome oxidases, in response to the available $\mathrm{O}_{2}$ (Poole, 1983). However this change is mediated, it must involve the coordinate expression and synthesis of two, or probably three, terminal oxidases. The control must affect the haem A biosynthetic pathway as well as oxidase structural polypeptides, as haem $\mathrm{A}$ is not found under $\mathrm{O}_{2}$-limited conditions.

R.K.P. thanks the Royal Society and the Smith Kline Foundation for equipment grants.

\section{References}

Castor, L. N. \& Chance, B. (1955). Photochemical action spectra of carbon monoxide-inhibited respiration. Journal of Biological Chemistry 217, 453-465. 
Castor, L. N. \& Chance, B. (1959). Photochemical determinations of the oxidases of bacteria. Journal of Biological Chemistry 234, 15871597

Chance, B., Saronio, L. \& Leigh, J. S. (1975). Functional intermediates in the reaction of membrane-bound cytochrome oxidase with oxygen. Journal of Biological Chemistry 250, 9226-9237.

Davis, G. H. G. \& PARK, R. W. A. (1962). A taxonomic study of certain bacteria currently classified as Vibrio species. Journal of General Microbiology 27, 101-119.

De Maio, R. N., Webster, D. A. \& Chance, B. (1983). Spectral evidence for the existence of a second cytochrome $o$ in whole cells of Vitreoscilla. Journal of Biological Chemistry 258, 13768-13771.

ERECKINSKA, M. \& CHANCE, B. (1972). Studies on the electron transport chain at subzero temperatures: electron transport at site III. Archives of Biochemistry and Biophysics 151, 304-315.

FUHRHOP, J. H. \& SMITH, K. M. (1975). Laboratory Methods. In Porphyrins and Metalloporphyrins, pp. 757-869. Edited by K. M. Smith. Amsterdam: Elsevier.

FUkOMORI, Y., FuJiWara, T., OKada-Takahashi, Y., Mukohata, Y. \& Yamanaka, T. (1985). Purification and properties of a peroxidase from Halobacterium halobium L-33. Journal of Biochemistry 98, 10551061 .

KeILIN, D. (1966). The History of Cell Respiration and Cytochrome. Cambridge: Cambridge University Press.

LORENCE, R. M., Koland, J. G. \& GenNIS, R. B. (1986). Coulometric and spectroscopic analysis of the purified cytochrome $d$ complex of Escherichia coli: evidence for the identification of 'cytochrome $a_{1}$ ' as cytochrome $b_{595}$. Biochemistry 25, 2314-2321.

LuDWIG, B. (1987). Cytochrome $c$ oxidase in prokaryotes. FEMS Microbiology Reviews 46, 41-56.

Markwell, M. A. K., HaAs, S. M., Bieber, L. L. AND Tolbert, N. F. (1978). A modification of the Lowry procedure to simplify protein determination in membrane and lipoprotein samples. Analytical Biochemistry 87, 206-210.

Matsushita, K., Yamada, M., Shinagawa, E., Adachi, O. \& AMEYAMA, M. (1983). Membrane-bound respiratory chain of Pseudomonas aeruginosa grown aerobically. A $\mathrm{KCN}$-insensitive alternate oxidase chain and its energetics. Journal of Biochemistry 93, $1137-1144$.

PooLE, R. K. (1977). The influence of growth substrate and capacity for oxidative phosphorylation on respiratory oscillations in synchronous cultures of Escherichia coli K12. Journal of General Microbiology 99, 369-377.

Poole, R. K. (1983). Bacterial cytochrome oxidases. A structurally and functionally diverse group of electron-transfer proteins. Biochimica et Biophysica Acta 726, 205-243.

Poole, R. K. (1988). Bacterial cytochrome oxidases. In Bacterial Energy Transduction, pp. 231-291. Edited by C. Anthony. London: Academic Press.

PoOLE, R. K. \& HADDOCK, B. A. (1974). Energy linked reduction of nicotinamide-adenine dinucleotide in membranes derived from normal and various respiratory-deficient mutant strains of Escherichia coli K12. Biochemical Journal 144, 77-85.

Poole, R. K. \& Williams, H. D. (1987). Proposal that the function of the membrane-bound cytochrome $a_{1}$-like haemoprotein ('cytochrome $\left.b_{59} s^{\prime}\right)$ in Escherichia coli is direct electron donation to cytochrome $d$. FEBS Letters 217, 49-52.

Poole, R. K., Lloyd, D. \& Chance, B. (1979a). The reaction of cytochrome oxidase with oxygen in the fission yeast Schizosaccharomyces pombe $972 \mathrm{~h}^{-}$. Biochemical Journal 184, 555-563.

Poole, R. K., Waring, A. J. \& Chance, B. (1979b). The reaction of cytochrome $o$ in Escherichia coli with oxygen. Low temperature kinetics and spectral studies. Biochemical Journal 184, 379-389.

Poole, R. K., Sivaram, A., Salmon, I. \& Chance, B. (1982). Photolysis at very low temperatures of CO-liganded cytochrome oxidase (cytochrome $d$ ) in oxygen-limited Escherichia coli. FEBS Letters 141, 237-241.

Poole, R. K., Baines, B. S., Curtis, S. J., Williams, H. D. \& Wood, P. M. (1984). Haemoprotein $b-590$ (Escherichia coli); redesignation of a bacterial 'cytochrome $a_{1}$ '. Journal of General Microbiology 130, 3055-3058.

Poole, R. K., Baines, B. S. \& Williams, H. D. (1985). Sensor sensationalism? Alternative views on the nature and role of 'cytochrome $a_{1}$ ' in bacteria. Microbiological Sciences 2, 21-24.

Poole, R. K., Baines, B. S. \& APPlebY, C. A. (1986). Haemoprotein b590 (Escherichia coli), a reducible catalase and peroxidase: evidence for its close relationship to hydroperoxidase I and a 'cytochrome $a_{1} b$ ' preparation. Journal of General Microbiology 132, 1525-1539.

Sone, N., Naqui, A., Kumar, C. \& Chance, B. (1984). Reaction of $\mathrm{caa}_{3}$-type terminal oxidase from the thermophilic bacterium PS3 with oxygen and carbon monoxide at low temperatures. Biochemical Journal 221, 529-533.

SPICHER, G. (1974). Cytochrome absorption spectra of bacteria as aid for solving taxonomic problems. 2nd Report: the redox and carbon monoxide difference spectra of bacterial species of the families Enterobacteriaceae and Pasteurellaceae, and of the genera Aeromonas, Xanthomonas, Vibrio, Acinetobacter, Alcaligenes, and Achromobacter. Zentralblatt für Bakteriologie, Mikrobiologie und Hygiene, Series $A$ 226, 541-553.

Stanier, R. Y., Palleroni, N. J. \& Doudoroff, M. (1966). The aerobic pseudomonads: a taxonomic study. Journal of General Microbiology 43, 159-271.

Wikström, M., KRAB, K. \& SARASTE, M. (1981). Cytochrome oxidase. A Synthesis. London: Academic Press.

Williams, H. D. \& Poole, R. K. (1986). Low temperature spectroscopic studies of cytochromes $a_{1}$ and $d$ in Acetobacter pasteurianus. Biochemical Society Transactions 14, 1215.

Williams, H. D. \& PoOle, R. K. (1987). The cytochromes of Acetobacter pasteurianus NCIB 6428. Evidence of a role for a cytochrome $a_{1}$-like haemoprotein in electron-transfer to cytochrome oxidase $d$. Journal of General Microbiology 133, 2461-2472.

Williams, H. D. \& Poole, R. K. (1988). Cytochromes of Acetobacter pasteurianus NCIB 6428: reaction with oxygen of cytochrome $o$ in cells, membranes and non-sedimentable subcellular fractions. Current Microbiology 16, 277-280.

WoOD, P. M. (1984). Bacterial proteins with CO-binding $b$ or $c$ type haem: functions and absorption spectroscopy. Biochimica et Biophysica Acta 768, 293-317. 